\title{
CUSTOMER RELATIONSHIP MANAGEMENT INFORMATION SYSTEM ST BORROMEUS HOSPITAL
}

\author{
Jimmy Bunardi ${ }^{1}$, Linda Salma Angreani, $\mathrm{MT}^{2}$ \\ ${ }^{1}$ Jurusan Teknik Informatika Fakultas Teknik Dan Ilmu Komputer Universitas Komputer \\ Indonesia \\ Jl. Dipati Ukur No. 112-116, Bandung 40132 \\ Email: jimmy.bunardi@gmail.com \\ 2 Jurusan Teknik Informatika Fakultas Sains dan Teknologi, Universitas Islam Negeri \\ Malang \\ Jl. Gajayana no 50, Malang65144 \\ Email: lindasalma@gmail.com
}

\begin{abstract}
Customer Relationship Management Information System St.Borromeus Hospitalis anapplication to process data related to the promotion, marketing and cooperation between the St.Borromeus Hospita lwith the Contractor. Data processing is not optimum cooperation with the contractorat the Marketing division of Borromeus Hospital,cause search of information about the contractor, take a bit longer so that hamper the process of promotion and marketing. Therefore it need an application that can support and solve the problem.
\end{abstract}

Based on these problems the author intends arrange final by taking the title of"Customer Relationship Management Information Systems St.Borromeus Hospital ". The technique is observation data collection, interview and library research, while the phase of system development using water fall method.

The author hopes that this application can assist the Marketing in the Hospital of St.Borromeusin the process of processing and marketing campaig $n$ to the Contractor, either from the input data, search data, scheduling agreements. The authors also hope that these applications can be made to improve the performance of the Marketing are using this application.

Keyword : Customer Relationship Management, BorromeusHospital, Marketing, Promotions

\section{INTRODUCTION}

St. Borromeus Hospital established since 1921, engaged in health continues to develop itself in line advancement in information technology, the influence of information technology on very large hospital, in improving services for patients / contractor (company partner) and the continuity of performance in the hospital.

The development of the St. Borromeus Hospital in line with the trust contactor to the hospital, demanding the St.
Borromeus Hospital improving service satisfaction and build strong relationships with contractors. So the relationship between hospitals and contractors maintained in the long term, thereby directly or, indirectly, to increase the number of subscribers.

During this time the St. Borromeus Hospital especially the marketing has not been managing customer data / 
contractor with good, to build stronger relationships with customers.

Therefore, the St. Borromeus Hospital need to implement a strategy that focuses on customer satisfaction and create customer loyalty and thus increase profits for hospitals, it is a CRM strategy.

CRM (Customer Relationship Management) is one method to develop a business strategy centered on the customer, who has a purpose that is using the relationship with customers to increase corporate profits, use information to provide the outstanding service, and support the sales process is repeated to the customer.

With the CRM, the hospital can effectively establish a good relationship with the contractor, and also help the marketing manage data related to the contractor so that customer information for marketing and promotional purposes can be obtained quickly.

Maintaining good relations with key customers effectively is to improve communication with customers, so building a relationship based on mutual understanding and trust. Therefore, to optimize the application of CRM to establish strong relationships with customers need the right tool, to enable the delivery of information to customers to quickly and easily, as well as supporting marketing operations including marketing automation, promotion, and service in order to become more leverage, and minimize cost.

Based on the description above, the authors interested in creating a final project with the title "Information Systems Customer Relationship Management Saint Borromeus Hospital."

\section{LITERATURE REVIEW}

\subsection{Definition of Customer Relationship Management}

CRM is defined as a single unit sales, marketing and service strategies that prevent the occurrence of work activities that are not coordinated between the well and it depends on the action - a coordinated action CRM companies concentrate on what is valued by customers, not on what the company wants to sell. Customers do not want to be treated equally. But they want to be treated individually. [8]

Martin, Brown, DeHayes, Hoffer \& Perkins add CRM system aims to provide an integrated approach to all aspects of the company in connection with its customers, which include marketing, sales and support. The purpose of this system is expected to occur with the use of technology, strong relationships between the company and its customers. In other words, companies try to manage the company with better performance. [9]

According to O'Brien CRM uses information technology to create crossfunctional enterprise systems that integrate and automate customer service processes in sales, marketing, and service products or services related to the company. IT CRM system also creates a framework that links all business processes with the company's operations. In addition, the CRM system also includes a set of software modules that help the company's business activities, such as the front office. CRM software is a tool that allows the company to provide fast service, excellent and consistent in its customers and can be illustrated in Figure 2.1. [9]

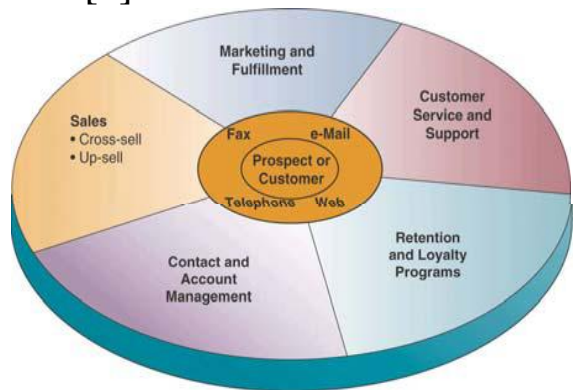

Figure 2.1. CRM Systems in Business Process

\subsection{CRM System Work}

Based on the opinion Budi Sutedjo CRM begins with gathering information 
about what is needed and expected by customers of the company. By knowing the needs and expectations of customers, the company can pamper and "tied" in a "friendship". According to the CRM concept for the company recommends opening channels of communication as easy as possible with a high response rate, so customers feel the closeness with the company. Thus, loyalty to the company will gradually develops and evolves. Thus the company will benefit from the implementation of this CRM, which has a loyal customer. Summarizing CRM Customer Relationship Management Activities in the figure 2.2. [2]

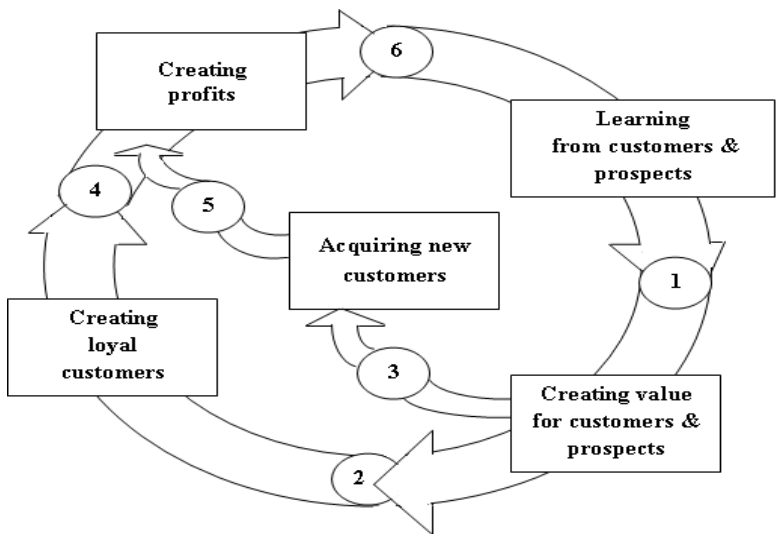

$\begin{array}{llll}\text { Figure } & 2.2 & \text { Summarizing } & \text { CRM }\end{array}$ Customer Relationship Management Activities

\subsection{Target CRM Business Framework}

The objectives of the CRM business framework are:

1. Using existing relationships to grow revenue.

2. Using integrated information for excellent service.

\section{ANALYSIS AND DESIGN}

\subsection{Flow Analysis Information Systems} CRM

Here is the analysis of flow of Customer Relationship Management Information System of the St. Borromeus Hospital can be seen in Figure 3.1.
3. Introducing consistent, replicable channel processes and procedures.

\subsection{The purpose of CRM}

The main objective of CRM is to manage and manage the customer to place a good relationship between companies and customers. The purpose of CRM by Kalakota, Robinson:

1. Optimizing existing customers to better enhance the company's earnings. Prepare complete information about customers to maximize customer relationships with companies through the sale of a up-selling and cross-selling that at the same time can increase profits by identifying, attracting and retain the best customers.

2. Using the information that is integrated to produce the most satisfactory service. Using the information needed by customers, our customers can save time and avoid customer complaints of various kinds of problems. For example, customers should not have to provide information about him repeatedly in the various departments, but the customer will be more happy if it turns out has been well recognized by the company.

Introduce procedures and production processes that are consistent though has been used repeatedly. With the increasing number of network subscribers, it will be many employees involved in sales transactions. Regardless of size or level of difficulty, the company must improve the consistency of processes and procedures in terms of management and sales. [8] 


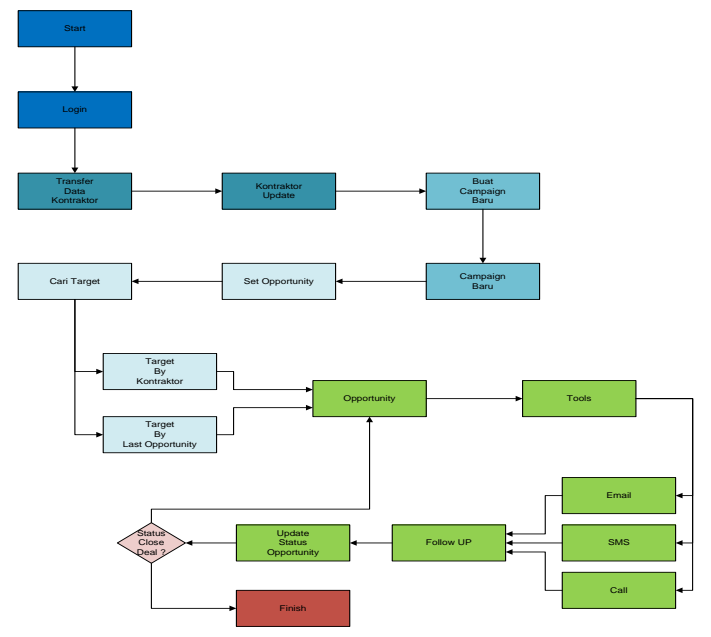

Figure 3.1 Design Flow of Information Systems CRM

\subsection{Framework CRM RSB}

Framework is a framework that is safe and can be developed further to run a business. Here is a framework for CRM Customer Relationship Management Information System for the St. Borromeus Hospital, can be seen in Figure 3.2.

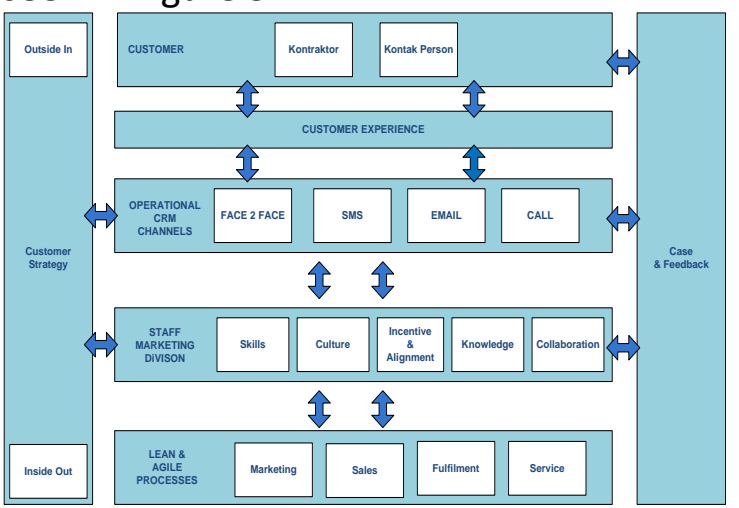

Figure 3.2 Framework of CRM Customer Relationship Management Information System of the St. Borromeus Hospital
Customer Strategy Layer: Layer start when determining a strategy to reach customers (contractors \& contact person).

Layer Customer: Customers, Contractors are working with RS Borromeus.

Customer Experience Layer: Layer represents the accumulated experience of customers CRM Operational Layer Channels: Layer Channel CRM to communicate and interact with customer / contractor.

Staff Marketing Devision Layer: Layer the most important of which is competent human resources staff have marketing skills, knowledge, and understanding the culture, and collaboration to run a CRM strategy. Lean \& Agile Processes Layer: This layer deals with all business processes associated with customer / contractor such as marketing, sales, and service. Case \& Feedback Layer: Layer where Case and feedback from customers / contractors to measure customer satisfaction to produce a better strategy.

\subsection{Context Diagram}

To limit the system shows the system interaction with external components of the system then needs to be made that the context diagram is a diagram illustrating the system in one environment and relationships with outside entities. Context diagram Customer Relationship Management Information Systems of St. Borromeus Hospital can be seen in Figure 3.6. 


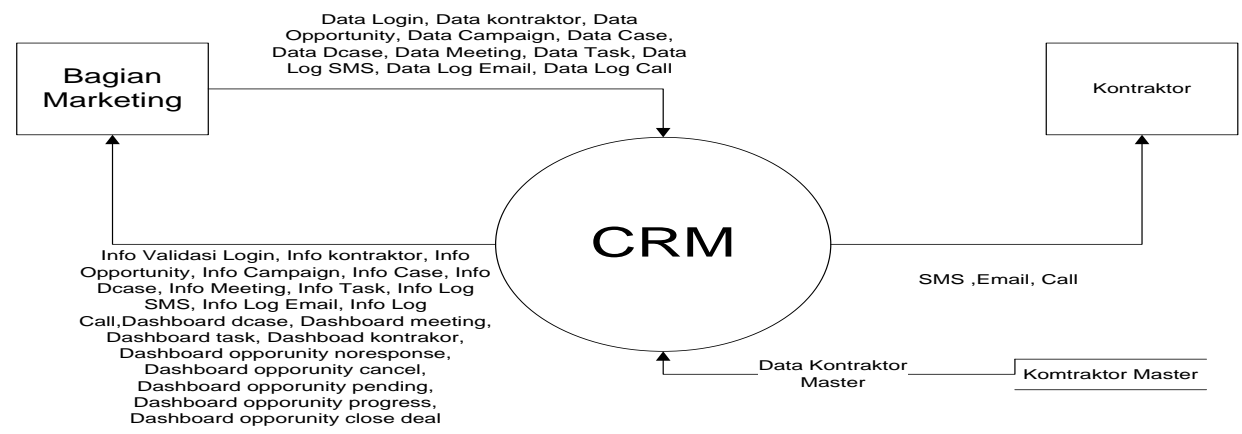

Figure 3.3 Diagram of the Context of Customer Relationship Management Information System of the St. Borromeus Hospital

context diagram of RSB CRM

3.4 Data Flow Diagram (DFD)

3.4.1 DFD Level 1 Information System CRM RSB

DFD Level 1 describes the sequence of processes that is derived from the
Information System. DFD Level 1 Customer Relationship Management Information System of the St. Borromeus Hospital can be seen in Figure 3.4.

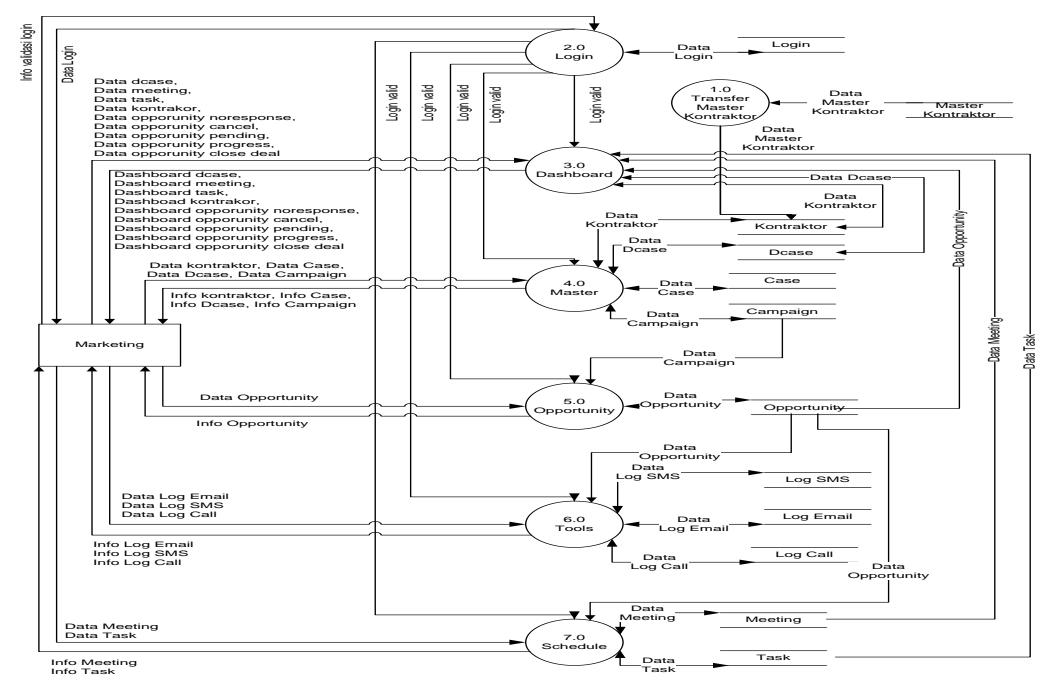

Figure 3.4 Level 1 DFD Customer Relationship Management Information System RSB

\section{CONCLUSIONS}

Based on the description of the discussion of research that has been done, it can be concluded as follows:

1. That the Information Systems Customer Relationship Management Borromeus Hospital to facilitate the marketing data management contractor for marketing and promotion.
That the Information Systems Customer Relationship Management Borromeus Hospital to facilitate the marketing of managing cases and

2. Feedback data from the contractor relating to the promotion done.

3. That the Information Systems Customer Relationship Management 
RS Borromeus facilitate the marketing in the search data on the contractor to re penjaulan / promotion.

4. That this application can to facilitate the marketing of sending message / sms marketing and promotion to the contractor.

\section{REFERENCES}

1. Babin, Lee. 2007. Beginning Ajax with PHP - From Novice to Professional.

2. Fatansyah, Ir. 1999. Basis data. Bandung. Informatika.

3. Janjicek, Rose. 2003 CRM architecture for enterprise relationship marketing in the new millennium.

4. Nicholas C. Zakas, Jeremy McPeak, Joe Fawcett. 2006. Professional AJAX.

5. Prihatna, Hengky. 2004. Kiat Praktis Menjadi Webmaster Profesional. Jakarta. Elek Media Komputindo.

6. Roger S. Pressman, Ph.D. 2002. Rekayasa Perangkat Lunak Pendekatan Praktisi (Buku Satu). Yogyakarta. ANDI.

7. Srivastava, Jaideep. 2006. Data Mining for Customer Relationship Management(CRM).

8. O’Brien, James A., 2002. Customer Relationship Management ", Management Information Systems: Managing Information Technology in the E-Business Enterprise (5th ed.), .), McGraw-Hill Higher Education.

9. Martin, E.W., Brown, C.V., DeHayes, D.W., Hoffer, J.A., Perkins, W.C., 2005, Customer Relationship Management Managing Information Technology 

